\title{
CYCLE LIFE PREDICTION OF LITHIUM-ION CELLS UNDER COMPLEX TEMPERATURE PROFILES
}

\section{PROGNOZOWANIE CYKLU ŻYCIA OGNIW LITOWO-JONOWYCH PRZY ZŁOŻONYCH PROFILACH TEMPERATUROWYCH}

\begin{abstract}
Nowadays, the extensive use of Lithium-ion cells requires an accurate life prediction model. Failure of Lithium-ion cells usually results from a gradual and irreversible capacity fading process. Experimental results show that this process is strongly affected by temperature. In engineering applications, researchers often use the regression-based approach to model the capacity fading process over cycles and then perform the cycle life prediction. However, because of neglecting temperature influences, this classic method may lead to significant prediction errors, especially when cells are subject to complex temperature profiles. In this paper, we extend the classic regression-based model by incorporating cell temperature as a predictor. Two effects of temperature on cell capacity are considered. One is the positive effect that high temperature lets a cell discharge more capacity in a cycle; The other is the negative effect that high temperature accelerates cell capacity fading. A cycle life test with six cells are conducted to valid the effectiveness of our method. Results show that the improved model is more suitable to capture the dynamics of cell capacity fading path under complex temperature profiles.
\end{abstract}

Keywords: Lithium-ion cells, capacity fade, complex temperature profiles, life prediction, reliability assessment.

\begin{abstract}
Obecne szerokie zastosowanie ogniw litowo-jonowych wymaga stworzenia trafnego modelu prognozowania ich trwałości. Uszkodzenia ogniw litowo-jonowych zazwyczaj wynikaja ze stopniowego i nieodwracalnego procesu utraty pojemności. Wyniki doświadczeń pokazuja, że na ten proces silny wplyw wywiera temperatura. W zastosowaniach inżynieryjnych, naukowcy czesto wykorzystuja podejście oparte na regresji do modelowania procesu utraty pojemności w poszczególnych cyklach by następnie dokonać prognozy trwałości $w$ danym cyklu pracy. Jednakże, ta klasyczna metoda nie bierze po uwage wpływu temperatury, co może prowadzić do znacznych błędów predykcji, w szczególności, gdy ogniwa pozostaja pod wpływem złożonych profili temperaturowych. W prezentowanym artykule, rozszerzono klasyczny model oparty na regresji poprzez właczenie temperatury ogniwa jako czynnika prognostycznego. Przeanalizowano dwa rodzaje wpływu temperatury na pojemność ogniw. Zjednej strony, wysoka temperatura oddziahuje pozytywnie pozwalając ogniwu na uzyskanie większej pojemności w danym cyklu; z drugiej strony jest to wpływ negatywny, ponieważ wysoka temperatura przyspiesza utratę pojemności ogniwa. Przy użyciu sześciu ogniw, przeprowadzono badanie trwałości $w$ danym cyklu pracy w celu potwierdzenia skuteczności naszej metody. Wyniki pokazuja, że udoskonalony model pozwala lepiej uchwycić dynamike ścieżki utraty pojemności ogniwa w warunkach złożonych profili temperaturowych.
\end{abstract}

Stowa kluczowe: Ogniwa litowo-jonowe, utrata pojemności, złożone profile temperaturowe, prognozowanie trwałości, ocena niezawodności.

\section{Introduction}

Lithium-ion cells have been widely applied to many portable consumer electronics, such as cell phones, laptops, digital cameras and so on [8]. Compared with other secondary batteries, Lithium-ion cells perform a large number of advantages, for example, no memorability, high nominal voltage, long cycle life, low self-discharge rate, high energy density and low pollution, etc., all of which make it one of the most ideal power sources in the $21^{\text {th }}$ century. The recent trend shows that Lithium-ion cells also have a brilliant future in the application of electric vehicles, defense industry and power storage for renewable energy sources. Cycle life is one of the most significant indices by which the performance of Lithium-ion cells can be measured. Therefore, how to accurately predict cycle life becomes crucially necessary for the popularization of Lithium-ion cells, especially for the Lithium- ion cells of special uses (such as the spacecraft power system), where imprecise prediction of cycle life can lead to consequences ranging from operation impairment to even catastrophic failures [9].

In many cases, an underlying degradation process can be traced to product failure [14]. Capacity is often treated as a key indicator measuring the performance degradation of Lithium-ion cells [3]. Many studies have focused on the cycle life prediction of Lithium-ion cells based on the capacity fading models. Meng et al. [13] studied the capacity fading curves of Lithium-ion power cells at a certain constant temperature, and then used the Weibull distribution to conduct the cycle life prediction. Wang et al. [18] investigated the cycling-induced capacity fading mechanisms in Lithium-ion cells and proposed a linear regression model to quantify the capacity loss over cycles. After studying the accelerated degradation test of numerous $\mathrm{LiFePO}_{4}$ cells, Lam and 
Bauer [10] proposed an empirical linear model describing the capacity fade, and the Arrhenius function was used to describe the fading rates under different temperatures. Besides the linear model, there are some studies centering on capacity fading models for different Lithium-ion type cells, such as the radical and linear model [19] and the quadratic and linear model [15].

These studies mentioned above, however, are mainly conducted based on the cycle life tests under one or more deterministic temperature levels, in which the high-precision temperature chamber and rigid data acquisition methods are required. Unlike the laboratory testing condition, cells in the field-use condition are usually run under complex temperature profiles. Previous researches indicate that the capacity fading process of Lithium-ion cells is significantly influenced by temperature $[5,7,10]$. In [10], capacity fading of Lithium-ion cells can be divided into true capacity fading and temporary capacity loss. True capacity fading leads to permanent capacity loss as a result of lithium ion and active material consuming, where high temperatures will accelerate the fading rate. On the other hand, temporary capacity loss is due to the temperature drop in a certain cycle, which is somewhat recoverable if the temperature goes back. A more accurate capacity fading model can be obtained by considering these temperature effects, especially for the cells operating under field-use conditions.

However, because of the difficulty in modeling the complicated temperature effects, the existing papers regarding capacity fading modeling or cycle life prediction under complex temperature profiles are very rare. In most of them, the classic regression-based approach [6] is adopted, which assumes that field conditions are deterministic or to simply use the mean value of temperatures while ignore their variability. This approach may result in significant prediction errors. For predicting the cycle life of Lithium-ion cells without the temperature chamber, this paper proposes a cycle life prediction method considering complex temperature profiles, including a cycle life test plan and an improved capacity fading model.

In our test, cells experience ambient temperature that continuously varies at all times. It will lead to the variance of cell capacity. The variance contains abundant information about cycle life and the relationship between cycle life and temperature. If we can effectively mine the information from the immense performance data using data modeling methods, the cycle life of Lithium-ion cells can be predicted accurately.

In this paper, firstly, the cycle life test plan for Lithium-ion cells under complex temperature profiles is introduced. Then, the classic regression-based life prediction method which ignores temperature effects is reviewed. Based on the classic method, we establish a more accurate capacity fading model, by taking into account the effects of temperature on both the actual capacity fading and the temporal capacity loss. Using the data acquired from the cycle life test, the parameters of the model are estimated. At last, the cycle life of this type of Lithium-ion cells is predicted.

\section{Experimental}

\subsection{Testing procedures}

In the cycle life test, $6 \mathrm{LiFePO}_{4} 18650$ cells, which are indexed

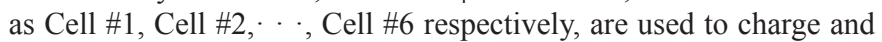
discharge repetitively. The parameters setup of these cells is listed in Table 1.

Fig. 1(a) and Fig. 1(b) show the scheme and photograph of our Lithium-ion cell cycle life test system, respectively. The system main-
Table 1. Parameters setup for $\mathrm{LiFePO}_{4} 18650$ cell

\begin{tabular}{||l|c|c||}
\hline Parameter & Value & Unit \\
\hline Rated capacity & 2000 & $\mathrm{mAh}$ \\
\hline Nominal voltage & 3.7 & $\mathrm{~V}$ \\
\hline End of charge voltage & 4.2 & $\mathrm{~V}$ \\
\hline End of discharge voltage & 2.75 & $\mathrm{~V}$ \\
\hline
\end{tabular}

ly consists of a personal computer, an ACCEXP battery test system and a temperature acquisition instrument $18 \mathrm{~B} 20$ with some thermocouples. The PC communicates with the ACCEXP battery test system that monitors the parameters of our interest, including current, voltage and capacity. The temperature measurement of each cell is performed by the thermocouples. And the temperature data are acquired and sent to the PC by the temperature acquisition instrument 18B20. Through the PC, we can set the charge/discharge algorithm for the ACCEXP battery test system.

According to the constant current/voltage charge and constant current discharge regime, cells are simultaneously tested as the following steps. (1) Charge with the constant current of $1 \mathrm{C}$ until the voltage reaches the end of charge voltage, then with the constant voltage

b)

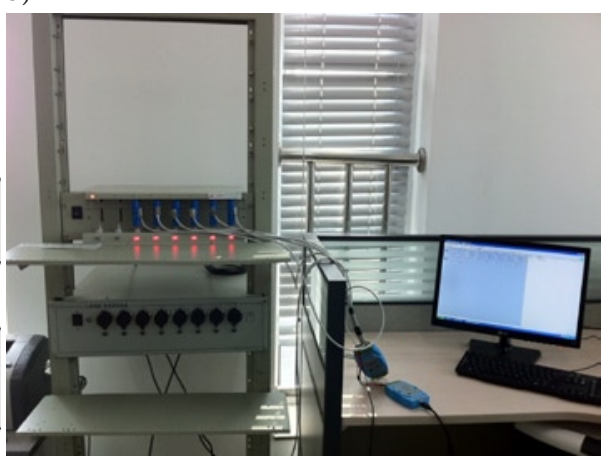

Fig. 1. Lithium-ion cells cycle life test platform
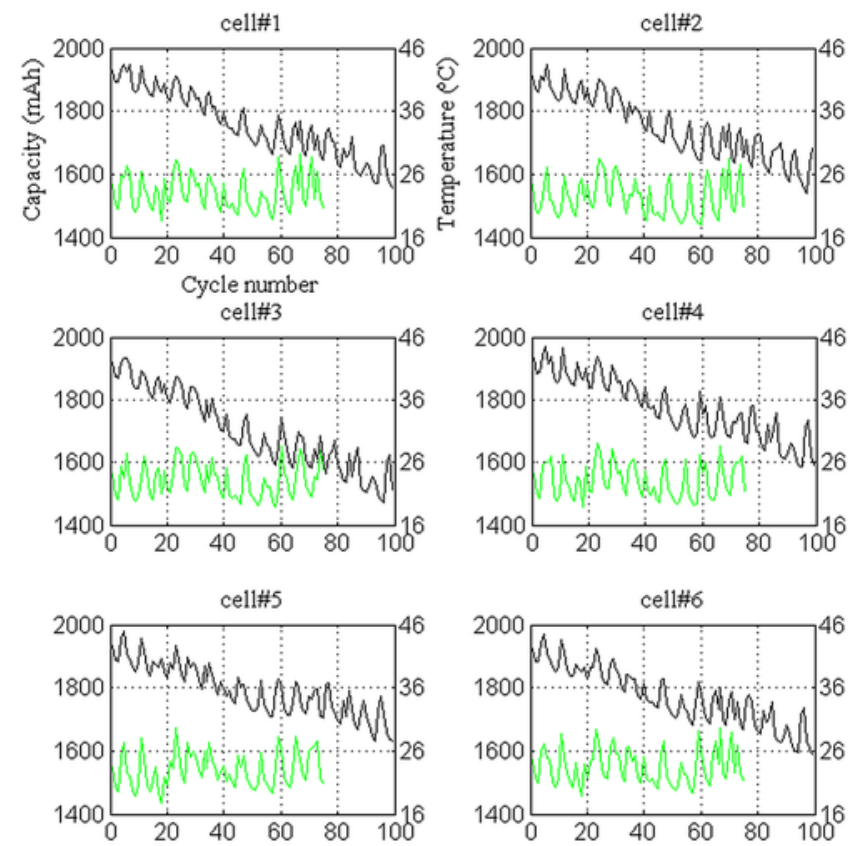

- Measured capacity $\longrightarrow$ Temperature

Fig. 2. Capacity fade and temperature variation versus cycle 
of until the current declines to C/100; (2) Stand by for 30 minutes; (3) Discharge the constant current of $1 \mathrm{C}$ until the voltage declines to the end of discharge voltage; (4) Stand by for 30 minutes; (5) Repeat the steps from (1) to (4) until the cycle number reaches 100.

For a $2000 \mathrm{mAh}$ cell, the $1 \mathrm{C}$ corresponds to a current of $2000 \mathrm{~mA}$. During the test, the temperature of each cell is measured every 10 seconds. Then, we can get the average Celsius temperature of each cell in each cycle. Because these cells are exposed to the ambient temperature, cell temperature varies irregularly with the ambient conditions over time, which is defined as complex temperature profiles in this paper.

The test results are illustrated in Fig. 2, it is clear that cell capacity fades gradually over cycles and correlates strongly with temperature. It is noted that the temperature signals after 75 th cycle are unavailable due to failure of the temperature acquisition instrument.

\subsection{Failure mechanism analysis}

Capacity fading is one of the main failure modes for secondary cells. Ideally, in addition to the reaction of the Lithium ion shuttling between two electrodes, there are no side reactions inside the cell. Thus the total amount of Lithium ion remains unchanged and cell capacity will not fade. However, during calendar storage or charge/discharge cycles, cell capacity fades gradually due to some unexpected side reactions, such as oxidation of anode materials, lithium corrosion on cathode, electrolyte decomposition and solid electrolyte interface (SEI) formation, among which the SEI formation usually dominates. During cycle life tests, the charge/discharge current produces diffusion induced stress and triggers cracks on the graphite particle. Consequently, it will lead to the SEI formation on the cracked surfaces, which will consume the active Lithium-ion. This diffusion-inducedstresses failure mechanism usually makes capacity fade linearly over cycles $[1,10,18]$.

\section{Classic cycle life prediction method}

\subsection{Capacity fading model ignoring temperature effect}

As cell temperature varies in a narrow range in the test, classic cycle life prediction methods often assume that temperature has no effect on the capacity fading process. In this case, we can regard the capacity fading data in Fig. 2 as a case of constant stress degradation tests, and the regression-based model is often used to handle this type of degradation data [6]. In the previous literature [1, 10, 18], capacity fading of Lithium-ion cells is generally assumed to follow a linear trend with cycles, namely:

$$
c(n)=a-b \cdot n,
$$

where the intercept $a$ and slope $b$ are unknown parameters, $c(n)$ is the cell capacity at nth cycle.

The estimators of model parameters for each cell can be obtained with the linear regression techniques. The end of life (EOL) for Lithium-ion cell is often defined as the number of charge/discharge cycles before cell capacity falls below $80 \%$ of its rated capacity [13]. Thus the failure threshold is set to be $2000 \times 80 \%=1600 \mathrm{mAh}$. Then we can calculate the cycle life $T$ of each cell, respectively. Because $T$ is an

Table 2. Parameter estimation and pseudo life (classic)

\begin{tabular}{||c|c|c|c|c|c|c||}
\hline & Cell\#1 & Cell\#2 & Cell\#3 & Cell\#4 & Cell\#5 & Cell\#6 \\
\hline$a$ & 1918.7 & 1894.3 & 1893.7 & 1920.8 & 1908.0 & 1906.5 \\
\hline$b$ & 3.3 & 3.0 & 3.9 & 3.0 & 2.3 & 2.7 \\
\hline$T$ & 97.8 & 98.8 & 75.9 & 107.6 & 131.1 & 111.7 \\
\hline
\end{tabular}

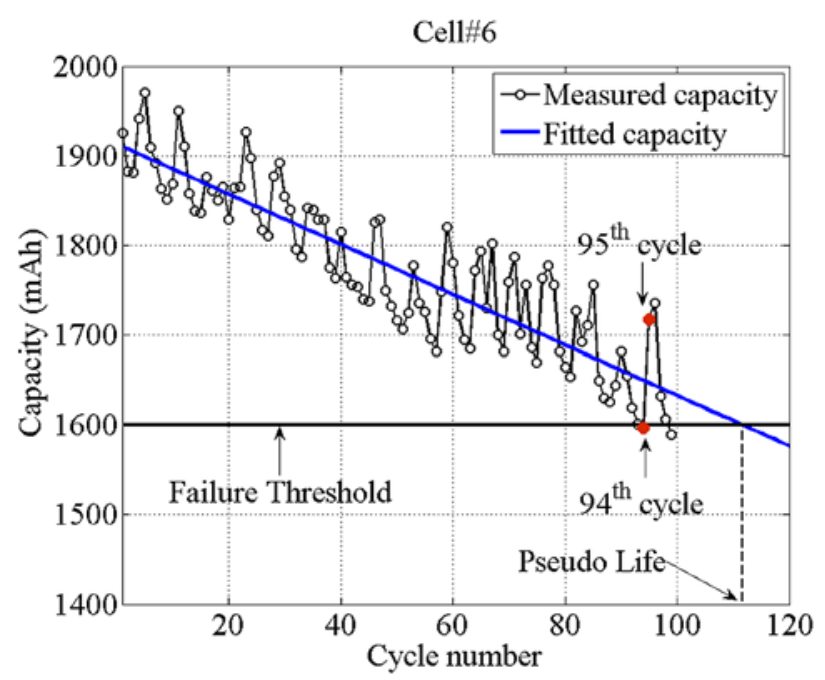

Fig. 3. Capacity fade plotted as a linear function of cycles

extrapolated life rather than the actual value, we call it pseudo life. The results of parameter estimation and pseudo life for each cell in the test are shown in Table 2. Take Cell \#6 as an example, the cycle life extrapolation method is illustrated in Fig. 3.

\subsection{Life prediction ignoring temperature effect}

Reliability is an important tool in lifetime prediction for components especially in the electronic industry [16]. Evaluating the reliability indices such as the MTTF (mean time to failure) and percentile of the cycle life distribution, is an essential task in cycle life prediction for Lithium-ion cells. What distribution the cycle life follows should be known before conduct the prediction. The Kolmogorov-Smirnov (K-S) goodness-of-fit test is used to test the goodness of some typical lifetime distributions [12]. Take a sample $x_{1}, \cdots x_{n}$, from a certain type of distribution $F$ and consider the two hypotheses:

$$
\left\{\begin{array}{l}
H_{0}: F(x)=F_{0}(x), \\
H_{1}: F(x)=F_{1}(x)
\end{array}\right.
$$

where $F$ is the empirical cumulative distribution function of the sample and $F_{0}(x)$ is a given cumulative distribution function.

The K-S statistic is:

$$
D_{n}=\sup \left|F_{0}\left(x_{i}\right)-F\left(x_{i}\right)\right|=\max \left\{\left|F_{0}\left(x_{i}\right)-\frac{i-1}{n}\right|,\left|F_{0}\left(x_{i}\right)-\frac{i}{n}\right|\right\} .
$$

Then we compare $D_{n}$ with $D_{n}^{\alpha}$, which is the cutoff value for determining whether $D_{n}$ is significant, where $\alpha$ is the significance level. If $D_{n}<D_{n}^{\alpha}$, we accept the null hypothesis $H_{0}$. Otherwise, we accept the alternative hypothesis $H_{1}$. The adequacy of the pseudo life distribution is judged by comparing $D_{n}$ calculated for the Weibull, Normal, Log-normal, Exponential and Gamma distribution. The K-S statistic for the five distributions are $0.182,0.204,0.232,0.519,0.212$ respectively, and the cutoff value $D_{n}^{\alpha}=0.52$ for $\mathrm{n}=6$ and $\alpha=0.05$. Results show that the Weibull has the minimum $D_{n}$, indicating that Weibull is better than the other four distributions for fitting these pseudo lives. Fig. 4 depicts the process of classic regression-based cycle life prediction method.

The probability density function $f(t)$, cumulative distribution function $F(t)$ and reliability function $R(t)$ of the Weibull distribution are given as follows: 


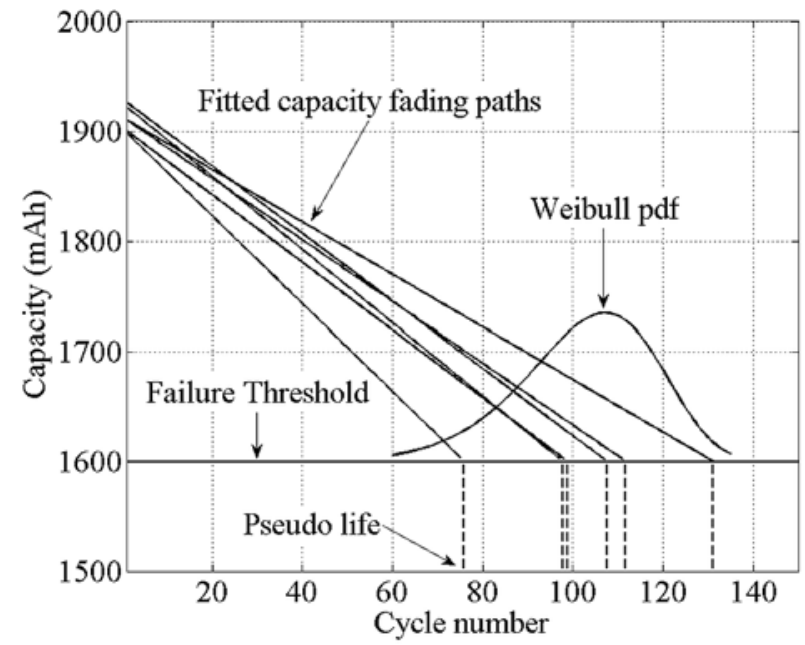

Fig. 4. Pseudo life distribution based on the Weibull distribution

$$
\left\{\begin{array}{l}
f(t)=\frac{m}{\eta}\left(\frac{t}{\eta}\right)^{m-1} \exp \left\{-\left(\frac{t}{\eta}\right)^{m}\right\} \\
F(t)=1-\exp \left\{-\left(\frac{t}{\eta}\right)^{m}\right\} \\
R(t)=1-F(t)
\end{array},\right.
$$

where $\eta$ is the scale parameter and $m$ is the shape parameter.

The Maximum Likelihood Estimate (MLE) of the Weibull parameters are: $\hat{\eta}=110.91$ and $\hat{m}=6.95$. Some indices of interest like MTTF (Mean time to failure) and $T_{\mathrm{q}}$ (the $100 q$ th percentile of lifetime distribution) can be obtained through (4). Because the sample in the test is small, we utilize the Parametric Bootstrap method to perform the interval estimate of these indices. For more information about Parametric Bootstrap method, see reference [4]. The point estimation and interval estimation with $80 \%$ confidence of $M T T F$ and $T_{\mathrm{q}}$ are shown in Table 3.

$$
\left\{\begin{array}{l}
M T T F=\int_{0}^{\infty} f(t) \mathrm{d} t \\
T_{q}=R^{-1}(q)
\end{array}\right.
$$

Table 3. Cycle life prediction results (Classic)

\begin{tabular}{|c|c|c|c||}
\hline MTBF & $T_{0.9}$ & $T_{0.8}$ & $T_{0.5}$ \\
\hline 103.2 & 80.2 & 89.4 & 105.2 \\
\hline$[94.3,112.4]$ & {$[69.1,97.2]$} & {$[79.6,103.4]$} & {$[96.0,114.4]$} \\
\hline
\end{tabular}

However, the classic cycle life prediction method has some drawbacks because it ignores the temperature effects on Lithium-ion cells. From Fig. 2, we can see that the temperature cycles and capacity cycles are correlated. In Fig. 3, although the cell's capacity dropped below $1600 \mathrm{mAh}$ in the $94^{\text {th }}$ cycle, it went back above $1700 \mathrm{mAh}$ in the next cycle due to temperature rising. Thus, besides cycle number, temperature is another factor that strongly affects capacity variation. In reality, the ambient environment and the battery's charge/discharge work together to cause its temperature fluctuation. Meanwhile, the varying temperature can in turn affect the reactions in the charge/discharge process and lead to the capacity fluctuation.
To study the correlation between temperature and cell capacity directly, we let the measured capacity in each cycle plus the degradation term $b \cdot n$ for compensating the cycle caused capacity variation. Then, the Pearson correlation test is conducted between the capacity after compensation and the temperature measured in the test. The correlation coefficients for the six cells are $0.94,0.96,0.92,0.94,0.85$ and 0.95 , respectively. Results indicate that the linear correlation between cell capacity and temperature is significant. To improve the accuracy of prediction, an improved cycle life prediction method is proposed by adding the temperature effects into the capacity fading model in Section 4.

\section{Improved cycle life prediction method}

\subsection{Capacity fading model considering temperature effects}

Numerous researches indicate that the capacity fading process of Lithium-ion cells is strongly affected by temperature. According to [11] and [15], the effect of temperature on the performance of lithiumion cells, on the one hand, is positive. High temperature enhances the activities of lithium ions and decreases internal resistance, which makes a cell release more capacity in a certain cycle. On the other hand, the effect is negative. It means that high temperature causes faster side reactions which bring permanent damage to cells. Meanwhile it accelerates capacity fade and shortens cell life. In the following parts, both of the two effects are considered in the improve regression model.

Firstly, we focus on the positive temperature effect. Based on the analysis in section 3.2, if we ignore the cycle caused capacity fade, the linear correlation between cell capacity and temperature is significant. Thus, the relationship between cell capacity and temperature can be modeled by a linear function:

$$
C(\text { temp })=\alpha+\beta \cdot \text { temp }
$$

where $C($ temp $)$ is the capacity a cell can discharge at temperature temp, $\alpha$ and $\beta$ are unknown parameters. The slope $\beta$ in (5) is positive, indicating that enhancing temperature will make a cell discharge more capacity in a cycle.

In practice, the actual capacity of a new cell fades linearly over charge/discharge numbers. As a result, the relationship between cell capacity and cycle number should be introduced into (5). Here we assume that the intercept term $\alpha$ accounts for the cycle caused capacity loss. Let $\Delta \alpha_{i}$ be the degradation increment between the $i^{\text {th }}$ cycle and the $(i-1)^{\text {th }}$ cycle, namely,

$$
\Delta \alpha_{i}=\alpha_{i}-\alpha_{i-1}, i=1,2, \cdots
$$

where $\alpha_{0}$ is the initial value of $\alpha$ for a totally new cell.

Now, the negative effect of temperature can be taken into account. As high temperature accelerates cell capacity fade, it is reasonable to use an Arrhenius function to model the relationship between temperature and capacity fading rate. Then, $\Delta \alpha_{i}$ can be expressed as,

$$
\Delta \alpha_{i}=-\exp \left\{\varphi+\frac{\eta}{\operatorname{temp}_{i}+273.15}\right\},
$$

where $A$ is unknown parameter, temp $_{i}$ is the average Celsius temperature in the $i^{\text {th }}$ cycle, $\varphi$ and $\eta$ are unknown parameters.

According to the cumulative exposure theory, the cumulative degradation value of can be obtained approximately by summing the 
degradation increment. Then, the remaining value of $\alpha$ after $n$ charge/ discharge cycles can be expressed as:

$$
\alpha_{n}=\alpha_{0}+\sum_{i=0}^{n} \Delta \alpha_{i}
$$

Then, a new capacity fade model under complex temperature profiles can be expressed as:

$$
C_{n}=\alpha_{n}+\beta \cdot \operatorname{temp}_{n}
$$

Substituting (7) and (8) into (9), we can obtain:

$$
C_{n}=\alpha_{0}-\sum_{i=0}^{n} \exp \left\{\varphi+\frac{\eta}{\operatorname{temp}_{i}+273.15}\right\}+\beta \cdot \operatorname{temp}_{n},
$$

where $C_{n}$ is the capacity a cell discharge in the $n^{\text {th }}$ cycle, temp $p_{n}$ is the temperature in the $n^{\text {th }}$ cycle, and $\left\{\right.$ temp $_{1}$, temp $_{2}$, temp $\left.p_{n}\right\}$ denotes the complex temperature profiles the cell experiences from the $1^{\text {st }}$ cycle to the $n^{\text {th }}$ cycle.

The nonlinear least square method is used to estimate the parameters in (10) for the six 6 cells respectively, and the results are shown in Table 4 .

Table 4. Parameter estimation of the improved capacity fade model

\begin{tabular}{||c|c|c|c|c|c|c||}
\hline & Cell\#1 & Cell\#2 & Cell\#3 & Cell\#4 & Cell\#5 & Cell\#6 \\
\hline$a_{0}$ & 1580.6 & 1642.4 & 1578.4 & 1670.8 & 1647.4 & 1554.1 \\
\hline$\varphi$ & 8.9 & 10.2 & 11.2 & 10.9 & 10.9 & 11.0 \\
\hline$\eta$ & -2255.9 & -2653.9 & -2892.4 & -2938.3 & -2907.1 & -2952.2 \\
\hline$\beta$ & 14.9 & 11.8 & 14.1 & 10.5 & 12.0 & 15.3 \\
\hline
\end{tabular}
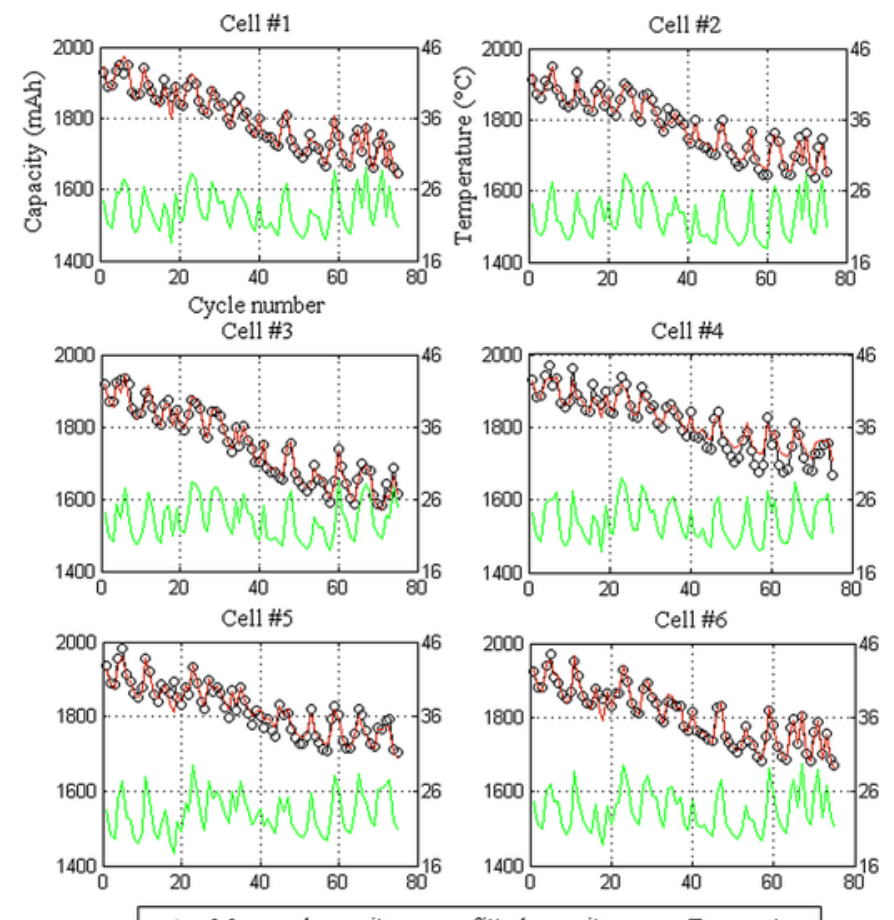

$\longrightarrow$ Measured capacity $\longrightarrow$ fitted capacity $\longrightarrow$ Temperature

Fig. 5. Capacity fade plotted using the improve model considering temperature effect
Substituting these estimators and the corresponding temperature profiles $\left\{\right.$ temp $_{1}$, temp $_{2}$, temp $\left._{75}\right\}$ (as only temperatures before the $75^{\text {th }}$ cycle are available) into (10), we can predict the capacity fading curves under complex temperature profiles. Fig. 5 compares the measured capacities and the predicted values for the six cells. It is clear that the measured capacities are consistent with the predicted value quite well. From the criteria aim to minimize the sum of the squares of the errors, the improved model is a more accurate parametric model than the classic one.

\subsection{Model cross-validation}

To further demonstrate the superiority of the improve capacity fading model over the classic one, the cross-validation method would be conducted in this section. In the cross-validation, we used 5 cells' data to build the model, and then validate it using the remaining one cell. The main steps are as follows: (1) Estimate the 5 cells' model parameters, respectively; (2) Calculate the mean values of the parameter estimators in (1); (3) Substitute the mean parameter estimators into the corresponding capacity fading model, and compare the results with the measured capacity of the remaining one cell. The results of cross-validation for the two models are illustrated in Fig. 6, respectively.

It is observed that for most of these cells (expect Cell \#3), the improved model is more suitable to capture the dynamics of cell capacity fading path under complex temperature profiles. Notice that, for Cell \#3, both the classic model and the improved one underestimate its capacity fading rate. This may be due to the fact that, capacity of Cell \#3 fades apparently faster than others, while the predicted model in cross-validation reflects the mean performance of the other five cells. To directly test the reasonability of the proposed model, the mean absolute error between the actual capacity and the predictions for each cell is calculated. The obtained results are summarized in Table 5. From Table 5, we can find that the improved model is more accurate than the classic regression model (except Cell \#3), which is consistent with Fig. 5.
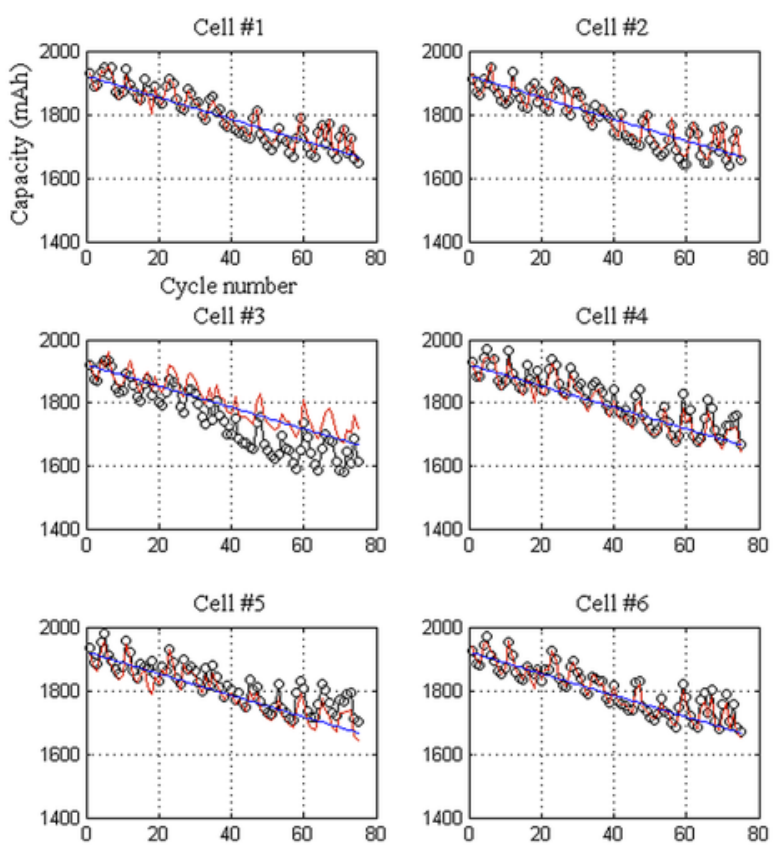

$\multimap$ Measured capacity $\longrightarrow$ Improved model —Classic model

Fig. 6. Cross-validation results 
Table 5. Mean predicted error of each cell (unit: $m A h)$

\begin{tabular}{|c|c|c|c|c|c|c|c|}
\hline & Cell\#1 & Cell\#2 & Cell\#3 & Cell\#4 & Cell\#5 & Cell\#6 & Total \\
\hline Improved & 9.86 & 9.70 & 59.68 & 20.09 & 26.26 & 9.40 & 135.00 \\
\hline Classic & 30.63 & 36.59 & 51.26 & 35.77 & 38.07 & 33.59 & 225.90 \\
\hline
\end{tabular}

\subsection{Life prediction considering temperature effect}

Using (10) we can predict the cell capacity fading path under a given complex temperature profile. Now we set the temperature to be deterministic, namely temp $p_{1}=t e m p_{0}$, for $i=1,2, \cdots$. Then, at the deterministic temperature temp $p_{0}$, the theoretical measured capacity of a cell after $n$ charge/discharge cycles can be predicted as:

$$
C\left(n, \text { temp }_{0}\right)=\alpha_{0}-\exp \left\{\varphi+\frac{\eta}{t e m p_{0}+273.15}\right\} \cdot n+\beta \cdot \text { temp }_{0}
$$

Generally, the rated capacity of Lithium-ion type cells refers to the capacity a new cell can discharge at room temperature, say temp $p_{1}=25^{\circ} \mathrm{C}$. Thus, an accurate definition of EOL (end of life) is the number of cycles when the capacity a cell can discharge at $25^{\circ} \mathrm{C}$ crosses the threshold value $D_{f}=0.8 C_{\text {rated }}$. However, $C\left(n\right.$, temp $\left.p_{0}\right)$ in (11) refers to the capacity a cell can discharge at temperature temp $p_{0}$ after $n$ cycles. In order to determine whether the cell really fails, we should firstly convert $C\left(n\right.$, temp $\left._{0}\right)$ to the equivalent capacity at room temperature, which is defined as room-temperature-capacity and denoted as $C^{\prime}\left(n\right.$, temp $\left._{0}\right)$.

According to (5), the difference between a cell's capacity at temp $p_{r}$ and temp $_{0}$ is:

$$
\Delta C\left(\text { temp }_{r}, \text { temp }_{0}\right)=\beta \cdot\left(\text { temp }_{r}-\text { temp }_{0}\right)
$$

The equivalent room-temperature-capacity for (11) can be expressed as:

$$
C^{r}\left(n, \text { temp }_{0}\right)=C\left(n, \text { temp }_{0}\right)+\beta \cdot\left(\text { temp }_{r}-\text { temp }_{0}\right),
$$

where $C\left(n, t e m p_{0}\right)$ is defined in (11) to denote the theoretical measured capacity of a cell after $n$ cycles at deterministic temperature temp $p_{0}$.

Using the new definition of EOL and (13), we can predict a Lithium-ion cell's cycle life under any specified temperature. The cycle life of a cell subject to deterministic temperature temp $p_{0}$ can be calculated by:

$$
T_{\text {temp }}=\left\{n \mid C^{r}\left(n, \text { temp } p_{0}\right)=D_{f}\right\}
$$

Note that our objective is to predict the life of these Lithium-ion cells under complex temperature profiles. Here, we use the mean value of the temperatures in the cycle life test to represent the complex temperature profiles. The mean temperature in our test is $23^{\circ} \mathrm{C}$, namely let temp $p_{0}=23^{\circ} \mathrm{C}$. Under this temperature, the pseudo life of the six cells is predicted using (14) respectively. The results are shown in Table 6. We can use these pseudo lives to represent the cells' cycle life under complex temperature profiles approximately.

We still use the Weibull, Normal, Log-normal, Exponential and Gamma distribution as the given distributions to conduct the K-S

Table 6. Pseudo life under complex temperature profiles

\begin{tabular}{||c|c|c|c|c|c|c||}
\hline \hline & Cell\#1 & Cell\#2 & Cell\#3 & Cell\#4 & Cell\#5 & Cell\#6 \\
\hline$T_{23^{\circ} \mathrm{C}}$ & 103.2 & 102.2 & 79.4 & 132.6 & 123.7 & 117.5 \\
\hline
\end{tabular}

goodness-of-fit test. The K-S statistic $D_{n}$ are $0.186,0.178$, $0.209,0.515,0.186$, respectively. This time, we see that the Normal distribution has the smallest $D_{n}$ rather than the Weibull distribution. The probability density function $f(t)$, cumulative distribution function $F(t)$ and reliability function $R(t)$ of the Normal distribution are given as follows:

$$
\left\{\begin{array}{l}
f(t)=\frac{1}{\sqrt{2 \pi} \sigma} \exp \left\{-\left(\frac{t-\mu}{\sigma}\right)^{2}\right\} \\
F(t)=\Phi\left(\frac{t-\mu}{\sigma}\right) \\
R(t)=1-F(t)
\end{array},\right.
$$

where $\mu$ is the mean, $\sigma$ is standard deviation and $\Phi(\cdot)$ is the cumulative distribution function of a standard normal distribution.

Using the technique of MLE, we can obtain the estimators of the Normal parameters: $\hat{\eta}=109.75$ and $\hat{\sigma}=109.75$. The corresponding indices MTTF and $T_{q}$ can be calculated by (4), too. The Parametric Bootstrap method is also used to obtain the confidence intervals of these indices. Table 7 gives the results of point estimation and $80 \%$ confidence intervals for MTTF and $T_{q}$ using the improved cycle life prediction methods.

Table 7. Cycle life prediction results (Improved)

\begin{tabular}{|c|c|c|c||}
\hline MTBF & $T_{0.9}$ & $T_{0.8}$ & $T_{0.5}$ \\
\hline 109.3 & 85.5 & 93.8 & 109.7 \\
\hline$[99.5,118.9]$ & {$[72.7,99.1]$} & {$[83.1,105.5]$} & {$[100.0,119.4]$} \\
\hline
\end{tabular}

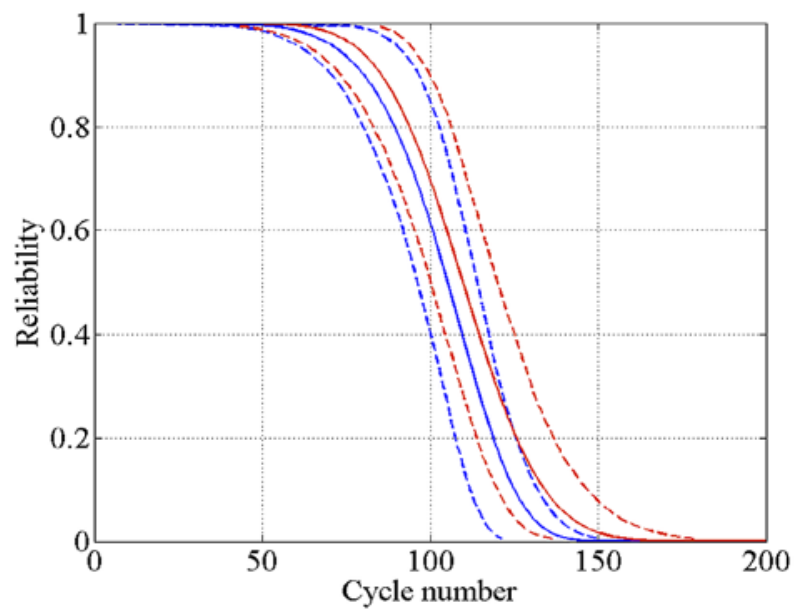

Fig. 7. Comparison of Lithium cell's reliability between classic method (blue) and improved method (red).

Fig. 7 compares the reliability plots of Lithium cells using classic method (blue) and the improve one (red). The $80 \%$ confidence intervals are obtained using the Parametric Bootstrap method and plotted in dotted lines. Compared with the improved method, the classic method underestimates the cell's reliability. The distribution type of cycle life also changes after considering temperature effects. In practical conditions, the amplitudes of temperature fluctuation may be more drastic than that in our test. In this case, ignoring temperature effects will lead to more significant prediction errors.

\section{Conclusion}

Many papers have been published on Lithium-ion cell life prediction, but they mainly focus on the laboratory settings where cells experience deterministic temperatures. In some field conditions, cells are tested without temperature controllers. In this case, cell capacity 
fades over time and is strongly affected by the temperature variations. In this paper, we extend the classis cycle life prediction method based on a regression model by considering the temperature effects. Comparisons are conducted between the classic and improved method, results show that the improved capacity fading model is more suitable to capture the characteristics of cell capacity fading paths under complex temperature profiles. With the advantages of low cost and easy popularization, the method of testing and analyzing cycle life in this paper can be conducted in field conditions and does not need to control the temperature accurately. In addition, the temperature of Lithium-ion cells in operation is always time-varying, so the model also provides a fundamental theory for the remaining useful life (RUL) prediction of Lithium-ion cells. The method proposed in this paper is a general method that can be applied to other batteries.

In the future work, two possible issues should be studied:
(1) Charge/discharge rates is another key parameter that affects Lithium-ion cell capacity fading processes. The model will be more complicated if both current rate and temperature are in complex profiles.

(2) Since the temperature in our test varies in a narrow range, the accelerated effect of high temperature on capacity fade is not significant enough. To verify the accelerated effect of high temperature, an accelerated degradation test under several temperature levels should be conducted.

\section{Acknowledgement}

The authors would like to thank the National Science Foundation of China under agreement 71271212 and 61304221, the Science Foundation of Hunan Province under agreement 14JJ3009 and the Innovation Foundation of National University of Defense Technology For Postgraduate under agreement B140504.

\section{References}

1. Arora P, White R E, Doyle M. Capacity fade mechanisms and side reactions in Lithium-ion batteries. Journal of Electrochemical Society 1998; 145(10): 3467-3667, http://dx.doi.org/10.1149/1.1838857.

2. Bloom I, Cole B W, Sohn J J, Jones S A, Polzin E G, Battaglia V S, Henriksen G L, Motloch C, Richardson R, Unkelhaeuser T, Ingersoll D, Case H L. An accelerated calendar and cycle life study of Li-ion cells. Journal of Power Sources 2001; 101: 238-247, http://dx.doi. org/10.1016/S0378-7753(01)00783-2.

3. Dubarry M, Svoboda V, Hwu R, Liaw B. Capacity and power fade mechanism identification from a commercial cell evaluation. Journal of Power Sources 2007; 165: 566-572, http://dx.doi.org/10.1016/j.jpowsour.2006.10.046.

4. Efron B. Bootstrap Confidence intervals for a class of parametric problems. Biometrika, 1985; 72: 45-58, http://dx.doi.org/10.1093/ biomet/72.1.45.

5. Fellner J P, Loeber G J, Sandhu S S. Testing of lithium-ion 18650 cells and characterizing/ predicting cell performance. Journal of Power Sources 1999; 81: 867-871, http://dx.doi.org/10.1016/S0378-7753(98)00238-9.

6. Freitas M A, Maria G T, Toledo M L G, Colosimo E A, Pires M C. Using degradation data to assess reliability: a case study on train wheel degradation. Quality and Reliability Engineering International 2009; 25:607-629, http://dx.doi.org/10.1002/qre.995.

7. Gui C Q. Influence of temperature on LiFePO4 Lithium-ion power battery. Battery Bimonthly 2011; 41(2): 88-91.

8. Inaba M, Ogumi Z. Up-to-date development of Lithium-ion batteries in Japan. Electrical Insulation Magazine 2001; 17(6): 6-20, http:// dx.doi.org/10.1109/57.969941.

9. Kim S Y, Caster J C, Saleh J H. Spacecraft electrical power subsystem: failure behaviour, reliability, and multi-state failure analyses. Reliability Engineering and System Safety 2012; 98: 55-65, http://dx.doi.org/10.1016/j.ress.2011.10.005.

10. Lam L and Bauer P. Practical capacity fading model for Li-Ion battery cells in electric vehicles. IEEE transactions on power electronics 2013; 28(12):5910-5918, http://dx.doi.org/10.1109/TPEL.2012.2235083.

11. Li Z, Han X B, Lu L G, Ouyang M G. Temperature characteristics of power LiFePO4 batteries. Journal of Mechanical Engineering 2011; 18: 115-120, http://dx.doi.org/10.3901/JME.2011.18.115.

12. Massey F. The Kolmogorov-Smirnov test for goodness of fit. Journal of the American Statistical Association 1951; 46: 68-78. http://dx.doi. org/10.1080/01621459.1951.10500769.

13. Meng X F, Sun F C, Lin C, Wang Z P. Cycle life prediction of power battery. Chinese Journal of Power Sources 2009; 33(11): $955-969$.

14. Nechval K N, Nechval N A, Berzins G, Purgailis M. Probabilistic assessment of the fatigue reliability. Eksploatacja i NiezawodnoscMaintenance and Reliability 2007; 3(35): 3-6.

15. Ramadass P, Haran B, White R, Popov BN. Mathematical modeling of the capacity fade of Li-ion cells. Journal of Power Sources 2003; 123(2): 230-240, http://dx.doi.org/10.1016/S0378-7753(03)00531-7.

16. Salvinder S K, Shahrum A, Nik A N. Reliability analysis and prediction for time to failure distribution of an automobile crankshaft. Eksploatacja i Niezawodnosc - Maintenance and Reliability 2015; 17(3): 408-415, http://dx.doi.org/10.17531/ein.2015.3.11.

17. Tang Z Y, Ruan Y L. Progress in Capacity Fade Mechanism of Lithium-ion Battery. Progress In Chemistry 2005; 1: 1-7.

18. Wang J, Purewal J, Liu P, Hicks-Garner J, Soukazian S, Sherman E, Sorenson A, Vu L, Tataria H, Verbrugge M W. Degradation of lithium ion batteries employing graphite negatives and nickel-cobalt-manganese oxide +spinel manganese oxide positives: Part 1, aging mechanisms and life estimation. Journal of Power Sources 2014; 269: 937-948, http://dx.doi.org/10.1016/j.jpowsour.2014.07.030.

19. Zhang Y C, Wang C Y. Cycle-life characterization of automotive lithium-ion batteries with LiNiO2 cathode. Journal of Electrochemical Society 2009;156(7): 527-535, http://dx.doi.org/10.1149/1.3126385.

\section{Tianyu LIU \\ Long CHENG \\ Zhengqiang PAN \\ Quan SUN}

College of Information System and Management

National University of Defense Technology

Sanyi Avenue, Changsha, China

E-mail:815487375@qq.com, sunquan@nudt.edu.cn 